\title{
EVALUATION OF WELDED FLANGE PLATE CONNECTIONS BETWEEN STEEL BEAMS AND BOX COLUMNS
}

\author{
M. Gholami, M. Tehranizadeh* and A. Deylami \\ Department of Civil and Environmental Engineering, Amirkabir University of Technology, Tehran, Iran \\ *(Corresponding author: E-mail: Dtehz@yahoo.com)
}

Received: 23 November 2011; Revised: 10 December 2011; Accepted: 20 February 2012

\begin{abstract}
This study elucidates the behavior of flange plate connection between a steel beam and a welded box column. Four finite element models simulating an exterior connection were prepared and analyzed. On the basis of finite element results, two flange plate connection details which are the reinforcing plate length and plate-to-flange fillet weld geometry were improved. Then, two full-scale specimens with flange plate connections were tested using a standard connection requalification test protocol. The flange plate connections of test specimens achieved the AISC seismic provision requirements for special moment frames.
\end{abstract}

Keywords: Connections, Flange plate, Box columns, Steel beam, Experimental program, Finite element analysis

\section{INTRODUCTION}

Box columns are frequently employed in areas of high seismic risk because they have an excellent capacity to resist biaxial bending. Cold-formed hollow sections are often used for low and medium rise buildings and built-up sections made up of four plates welded together are used for high rise buildings [1]. Extensive studies have been carried out and several new connection details have been proposed for the connection of I-beams to wide flange columns since the 1994 Northridge earthquake[2-7], but limited research for the connection of I-beams to box-columns has been conducted[8].

Kim et al. [9, 10] tested two full-scale moment connections to US box columns fabricated using pre-Northridge connection details. Test results revealed that both specimens failed by brittle fracture of complete joint penetration (CJP) welds between the beam flange and the column during a story drift angle of less than $1 \% \mathrm{rad}$, which resulted in no plastic rotation in the connections.

Chen et al. [8] tested six large scale specimens of steel beam-to-box column connections. One of the test specimens was the unreinforced connection using pre-Northridge details, and other test specimens were the reinforced connections using rib plates or wing plates. The unreinforced connection was failed by fracture in the heat affected zone (HAZ) of the beam bottom flange during $2.3 \%$ story drift angel cycle.

In the present study the behavior of a moment resisting connection, shown in Figure 1, has been investigated. This type of connection is mainly fabricated on site similar to a welded flange plate (WFP), which is considered as a prequalified connection in accordance with FEMA [11]. The shapes of the top and bottom flange plates are different due to the field construction of the connection at the site. The geometry of these plates is considered in a manner that site welding in a horizontal position is possible for connecting flange plates to beam and column. The WFP connections using rectangular and trapezoidal shapes of flange plates connecting to the $\mathrm{H}$ shape columns have already been tested $[12,13]$. 
A special welding sequence should be followed to join the continuity plates to the box column plate. As shown in Figure 2, after groove welds are performed to join the continuity plates to three plates of box column, the fourth plate should cuts into three segments. As shown in Figure 2, first, middle segment put into the place and CJP groove welds of continuity plates to this segment will be done. Finally, three segments will weld to each other.

This study analytically and experimentally investigates the behavior of the WFP connections. On the base of finite element results, an improved WFP connection was proposed. Then, two full-scale specimens with flange plate connections were tested using a standard connection prequalification test protocol. The results of the specimen's hysteretic behavior were obtained and compared to the AISC seismic provision requirements in order to qualify the improved flange plate connection.

\section{NONLINEAR FINITE-ELEMENT ANALYSIS}

Finite-element analysis can provide considerable insight into behavior of complex connections even though the analysis cannot readily address material imperfections, geometric imperfections, residual stresses and strains, and defects.

\subsection{Specimens}

Four models were prepared to simulate an exterior T-shaped joint subassembly. The general configuration of the exterior joint subassembly is shown in Figure 3. All models consisted of a $\mathrm{H}$-shaped steel beam with the dimensions of $\mathrm{H}-380 \times 200 \times 8 \times 12(\mathrm{~mm})$ connected to a box column with the measurements of B-400 $\times 400 \times 20 \times 20(\mathrm{~mm})$. The width-thickness ratios of the beam flange and the web are 8.33 and 44.5 , respectively, and the beam section categorizes to a compact section, which is capable of developing the fully plastic stress distribution.

Summary information on models is presented in Table 1. Model UN represents an unreinforced connection. Connection details of model UN is presented in the Figure 4. In the remaining three models, the joint from the steel beam to the box column was a WFP moment connection. Figure 5 shows connection details of model LF30. In the model LF30, flange plates were joined to the beam flanges with longitudinal fillet welds only. Model LF30-T was identical to LF30 except for the addition of the transverse fillet weld at the nose of the flange plate; the size of the LF30-T fillet welds was smaller than that of LF30 to preserve the total volume of fillet weld material. Figure 6 is a plan view of the fillet welds of LF30 and LF30-T. Model LF50-T was most similar to model LF30-T except that the flange-plate length was arbitrarily increased from 300 to $500 \mathrm{~mm}$.

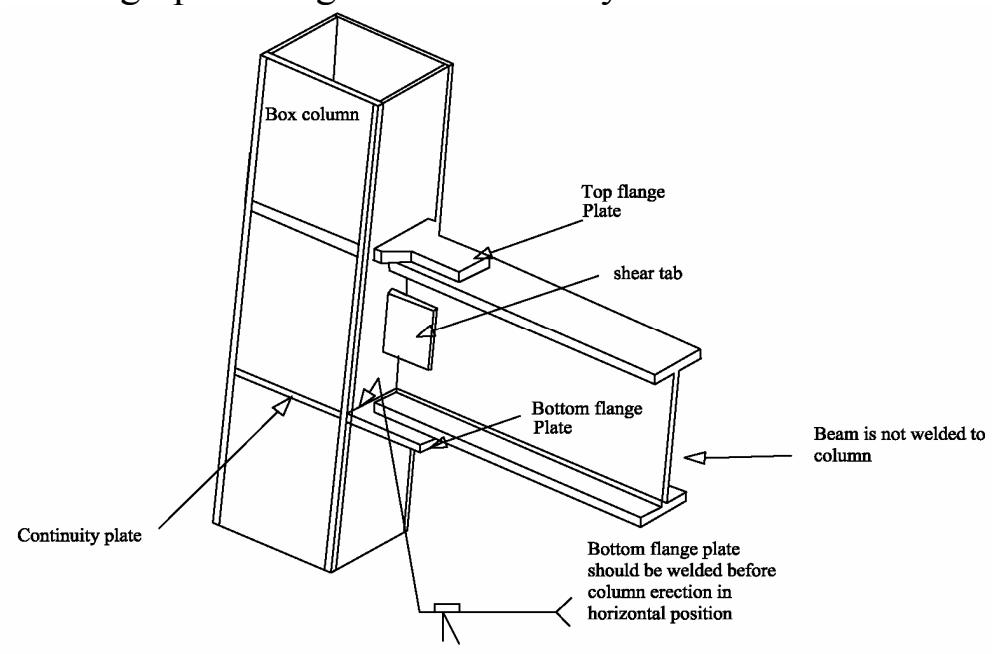

Figure 1. Field Welded Moment Connection 


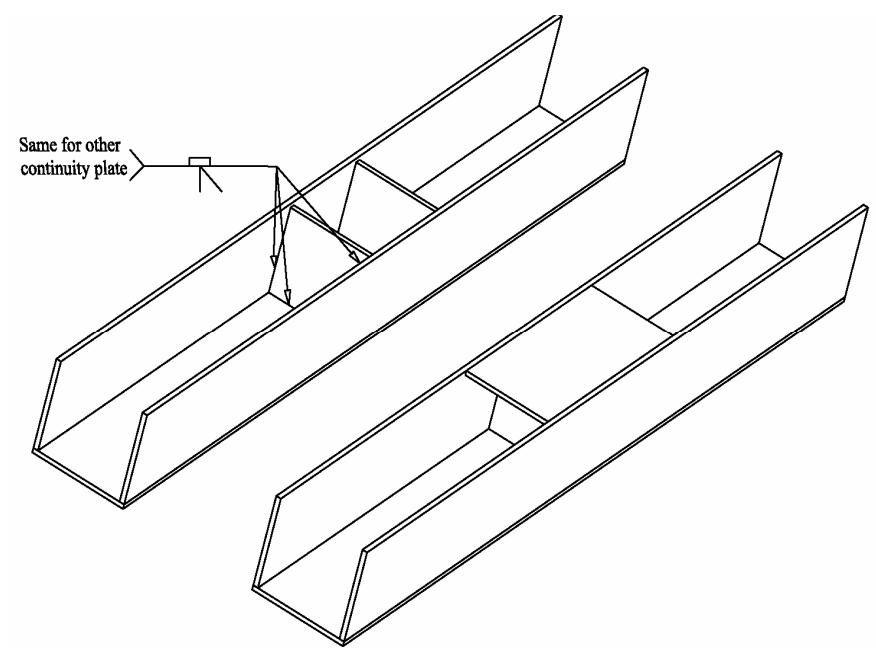

Figure 2. Welding of Continuity Plates to the Box Column Plates

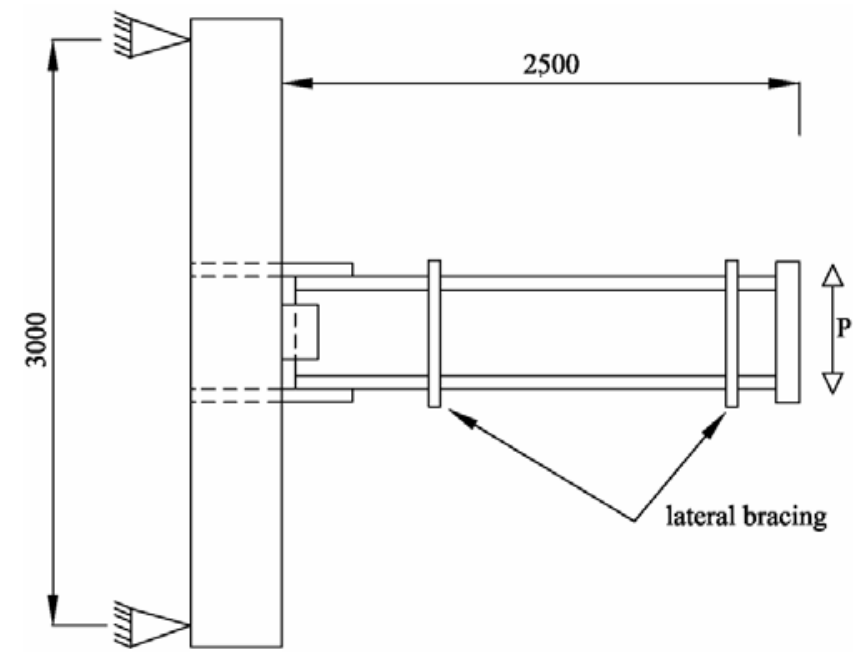

Figure 3. Configuration of the Exterior Joint Subassembly

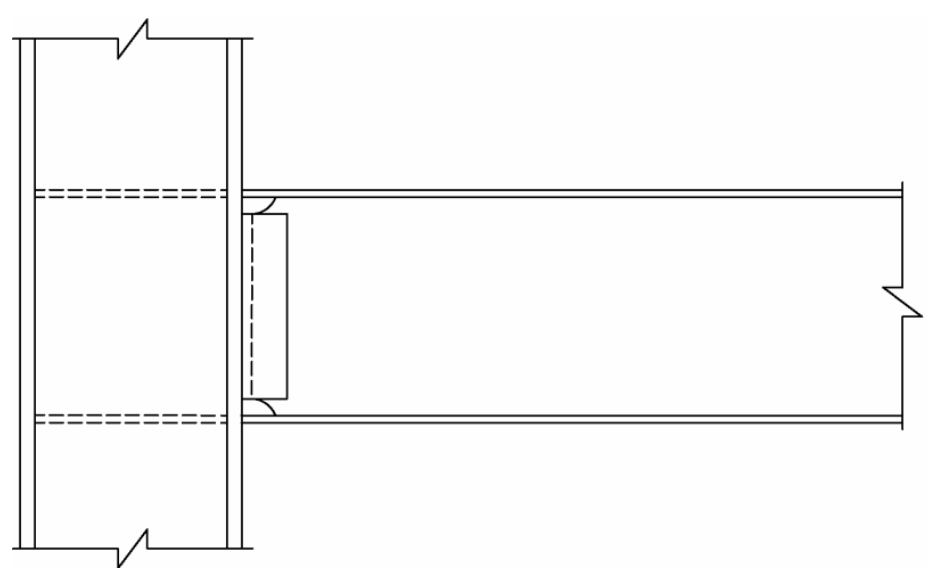

Figure 4. Connection Details of Model UN 

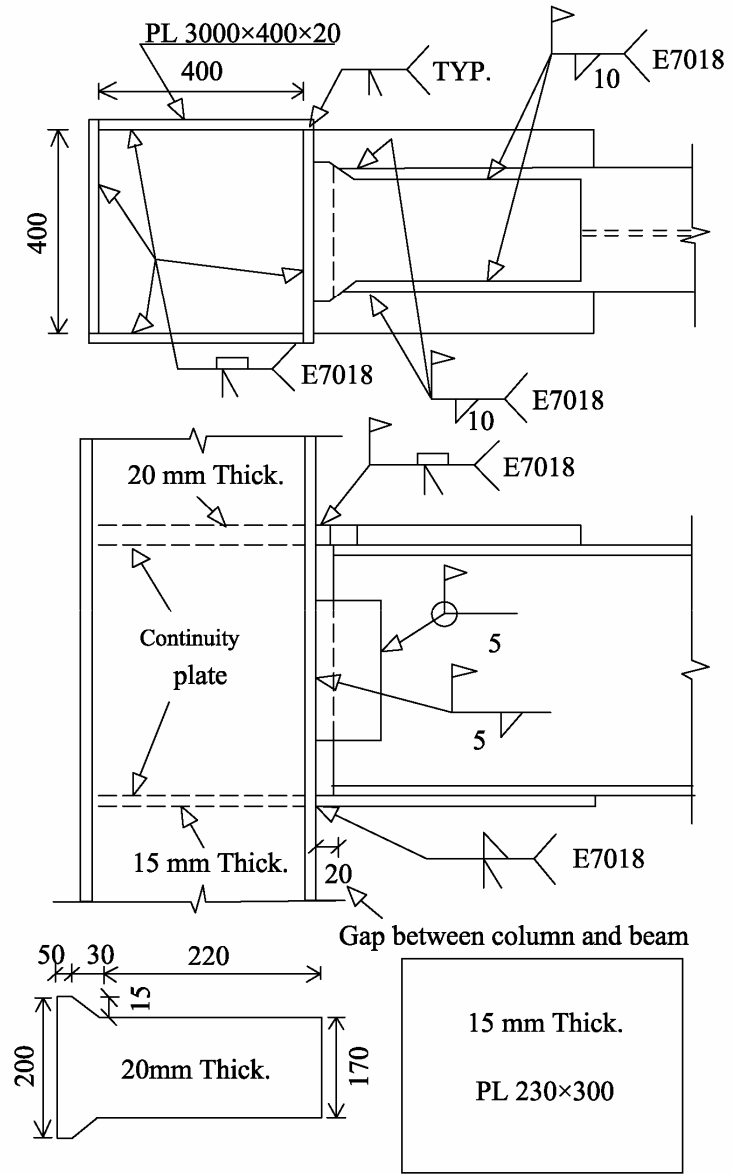

Top reinforcing flange plate Bottom reinforcing flange plate

Figure 5. Connection Details of Model LF30

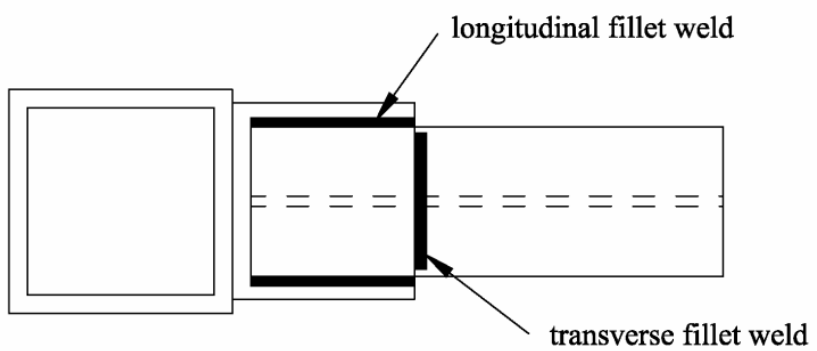

a)

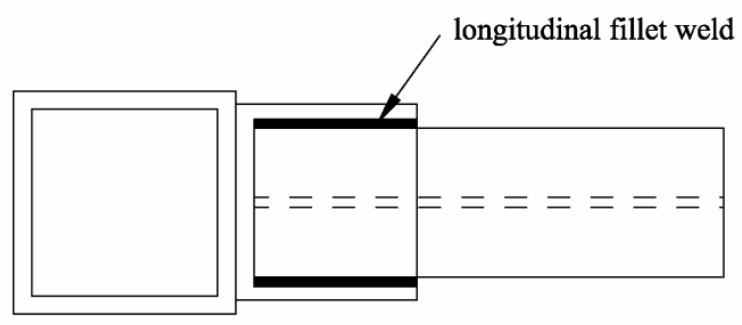

b)

Figure 6. Fillet Weld Geometry: (a) LF30-T and (b) LF30 
Table 1. Summary Information on Models

\begin{tabular}{|c|c|c|c|c|c|c|}
\hline Model & $\begin{array}{l}\text { Connection } \\
\text { type }\end{array}$ & $\begin{array}{c}\text { Flange-plate } \\
\text { length }\end{array}$ & $\begin{array}{c}\text { Top } \\
\text { flange-plate } \\
\text { thickness }\end{array}$ & $\begin{array}{c}\text { Bottom } \\
\text { flange-plate } \\
\text { thickness }\end{array}$ & $\begin{array}{l}\text { Longitudinal } \\
\text { fillet weld }\end{array}$ & $\begin{array}{l}\text { Transverse } \\
\text { fillet weld }\end{array}$ \\
\hline UN & Unreinforced & -------- & ------- & ------- & ------- & -------- \\
\hline LF30 & Flange plate & 300 & 20 & 15 & 10 & ------- \\
\hline LF30-T & Flange plate & 300 & 20 & 15 & 8 & 8 \\
\hline LF50-T & Flange plate & 500 & 25 & 20 & 8 & 8 \\
\hline
\end{tabular}

Note: All dimensions in $\mathrm{mm}$.

\section{$2.2 \quad$ Finite Element Modeling}

ABAQUS models of UN, LF30, LF30-T and LF50-T were prepared. As shown in Figure 7, groove welds that join flange plates to column flange and fillet welds that join flange plates and shear tabs to the beam were modeled. The beam, column, plates, CJP groove welds and fillet welds in the models were discretized using three-dimensional solid (brick) elements.

The size of the finite-element mesh varied over the length and height of the specimen as can be seen in Figure 7. A fine- mesh was used near the connection of the beam to the column and the beam flange to the reinforcing plate. A coarser mesh was used elsewhere. Most of the solid elements were right-angle prisms. Hinged boundary conditions were used to support the column top and bottom. The load was applied by imposing incremental vertical displacements at the beam tip during the analysis.

A bilinear stress-strain relationship was considered for each of materials. Figure 8 shows the assumed bilinear stress-strain relationship. Table 2 presents the material properties used for the analytical models. Data from test of coupon extracted from the beam of test specimen LF30-T were used to establish the stress-strain relationship for the steel material. The weld material was modeled using the test data of Kaufmann [14]. The Poisson's ratio was taken as 0.3 for all materials throughout the analyses. To account for material nonlinearities, the von mises yield criterion was employed.

\subsection{Rupture Index}

To compare between the behavior of the different configurations analyzed in this research, a rupture index was used and computed for different cases; this same methodology and approach was used by others $[13,15-18]$. The rupture index (RI) is defined as:

$$
R I=\frac{P E E Q}{\exp \left(-1.5 \frac{\sigma_{m}}{\bar{\sigma}}\right)}
$$

Where, $\sigma_{\mathrm{m}}$ and $\bar{\sigma}$ are, respectively, the equivalent plastic strain, hydrostatic stress, and von mises stress. The rupture index was introduced by Hancock and Mackenzie [19]. Locations in a connection with higher values of RI have a greater potential for ductile fracture. 


\subsection{Analytical Results}

The rupture index was computed at three locations, the top surface of the beam flange at the column face, at the nose of the reinforcing plate and the top surface of the reinforcing plate at the face of the column. The maximum values of stress and strain along these lines were not necessarily the maximum values in the components, but these lines were chosen to facilitate a comparison of results for different specimens. A story drift angle of $4 \%$ rad was used to compare the connection behaviors under highly strained states because a special moment-resisting frame is assumed to be capable of sustaining a story drift angle of at least $4 \% \operatorname{rad}[20]$.
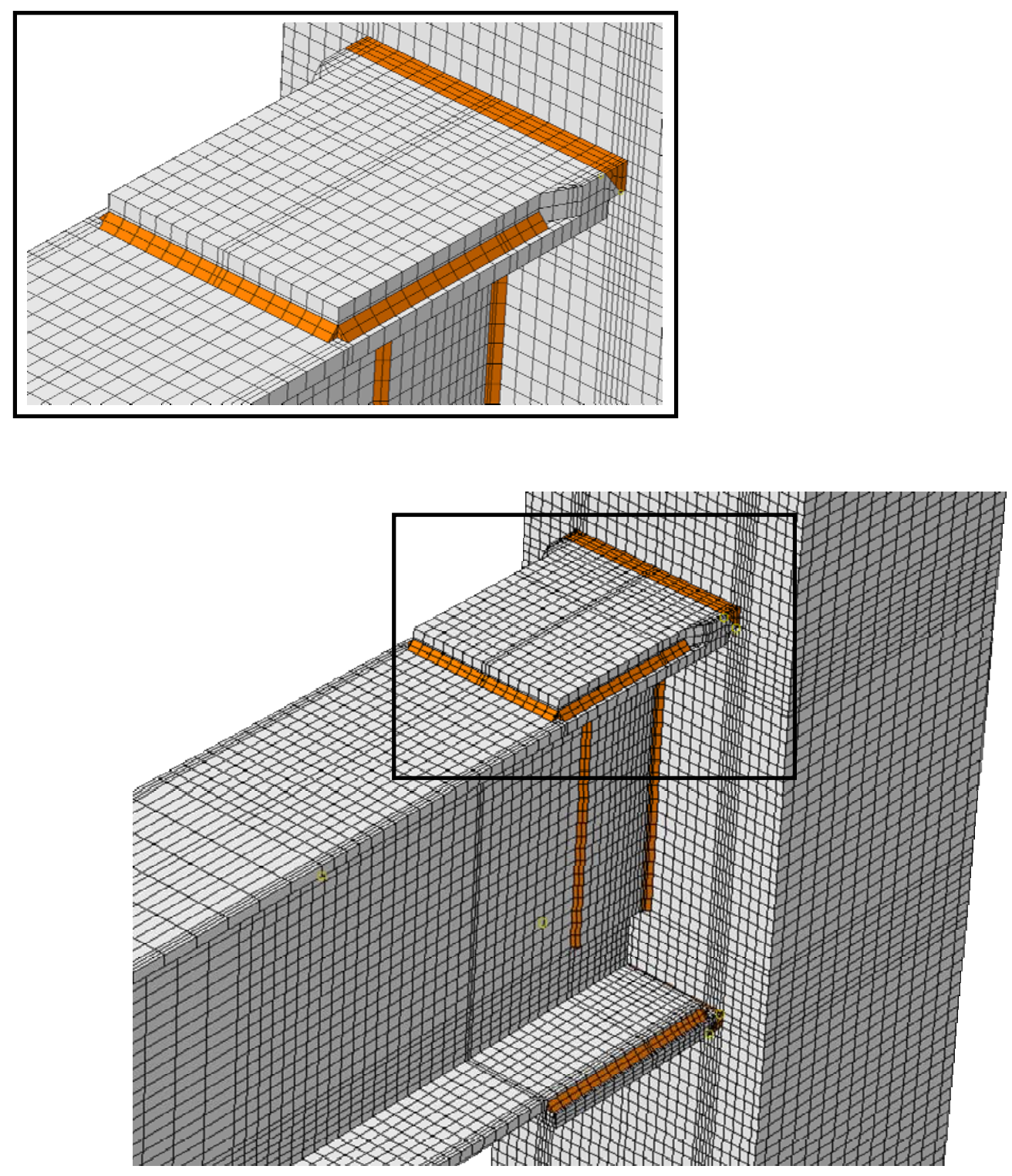

Figure 7. Finite Element Model 
Table 2. Material Properties used for the Analytical Models

\begin{tabular}{|l|l|l|l|l|l|l|}
\cline { 4 - 6 } \multicolumn{2}{c|}{} & \multicolumn{2}{l|}{ Yield point } & \multicolumn{2}{l|}{ Ultimate point } \\
\hline Material & $\begin{array}{l}\text { Young } \\
\text { modulus(Mpa) }\end{array}$ & $\begin{array}{l}\text { Strain hardening } \\
\text { modulus(Mpa) }\end{array}$ & $\begin{array}{l}\text { Stress(Mpa) } \\
\sigma_{\mathbf{y}}\end{array}$ & $\begin{array}{l}\text { Strain (\%) } \\
\varepsilon_{\mathbf{y}}\end{array}$ & $\begin{array}{l}\text { Stress(Mpa) } \\
\sigma_{\mathbf{u}}\end{array}$ & $\begin{array}{l}\text { Strain (\%) } \\
\varepsilon_{\mathbf{u}}\end{array}$ \\
\hline Steel & 200000 & 6000 & 300 & 0.15 & 4200 & 18 \\
\hline Weld & 200000 & 3000 & 520 & 0.26 & 560 & 12 \\
\hline
\end{tabular}

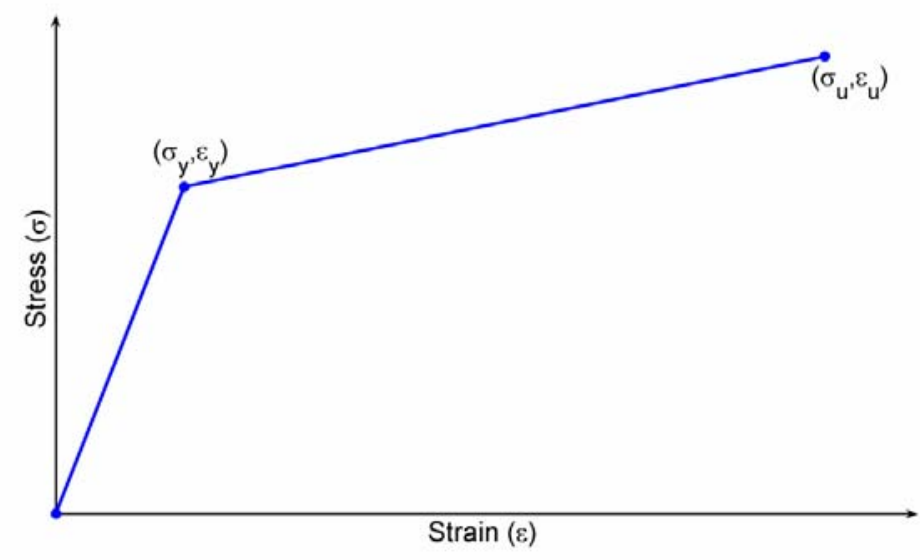

Figure 8. Assumed Bilinear Stress-strain Relationship for ABAQUS Models

\subsubsection{Comparison between the Behavior of Unreinforced and Flange Plate Connections}

To compare between the behavior of unreinforced and reinforced connections, the finite element models of LF30-T and UN were studied.

Figure 9 presents information on the distributions of the RI for models UN and LF30-T at the face of the column. The maximum value of the RI of $\mathrm{UN}$ is approximately 0.22 and is recorded at the edge of the beam flange. The largest value of RI is approximately 0.05 for LF30-T. The maximum value of the RI of UN is approximately four times greater than that of LF30-T. This indicates that the use of the flange plate connection will reduce the likelihood of ductile fracture of steel moment-resisting connections as compared to the unreinforced connection.

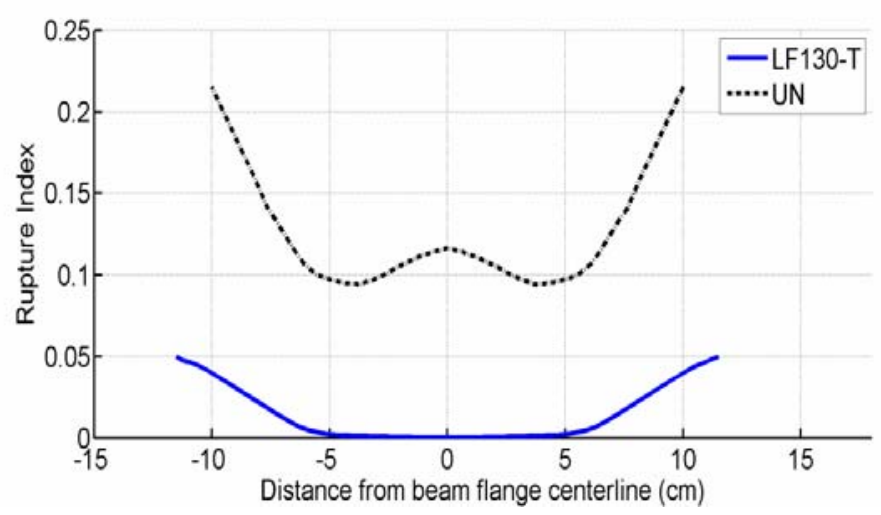

Figure 9. Distribution of Rupture Index at the Face of the Column for Models UN and Model LF30-T 


\subsubsection{Influence of Connection Details on the Response of Connection}

\section{- Fillet Weld Profiles}

Two fillet weld (two-sided and three-sided) profiles were studied in this research. To compare the fillet weld profiles, the responses of two specimens LF30 (L-L fillet weld), LF30-T (L-L-T fillet weld), are compared below.

Figure 10 shows the distributions of the RI for LF30 and LF30-T on the beam bottom flange at the nose of the bottom reinforcing plate. As can be seen in the Figure 10, the maximum value of the RI is recorded at the end of the longitudinal fillet weld of LF30. The maximum value of the RI is 0.45 for LF30, whereas its value is merely 0.2 for LF30-T. This reveals that addition of the transverse fillet weld at the nose of the flange plate substantially reduces the maximum value of the RI . There is a possible explanation for this phenomenon:

Consider the 2-sided fillet weld (longitudinal fillet welds only) and the end of the fillet weld at the nose of the reinforcing plate. The gap between the beam flange and the reinforcing plate at the bottom of the vertical leg of the fillet weld acts as an initial defect. The resulting stress concentrations and a state of triaxial tension at the end of the longitudinal fillet weld substantially increase the RI values. The addition of a transverse fillet weld eliminates the defect at the base of the vertical leg of the longitudinal fillet weld and reduces the stresses and triaxial tension at the end of the longitudinal fillet weld. Construction-related issues aside and based on the ABAQUS analysis data only, the 3 -sided fillet weld (2 longitudinal welds and 1 transverse weld) is superior to the 2-sided fillet weld (2 longitudinal welds).

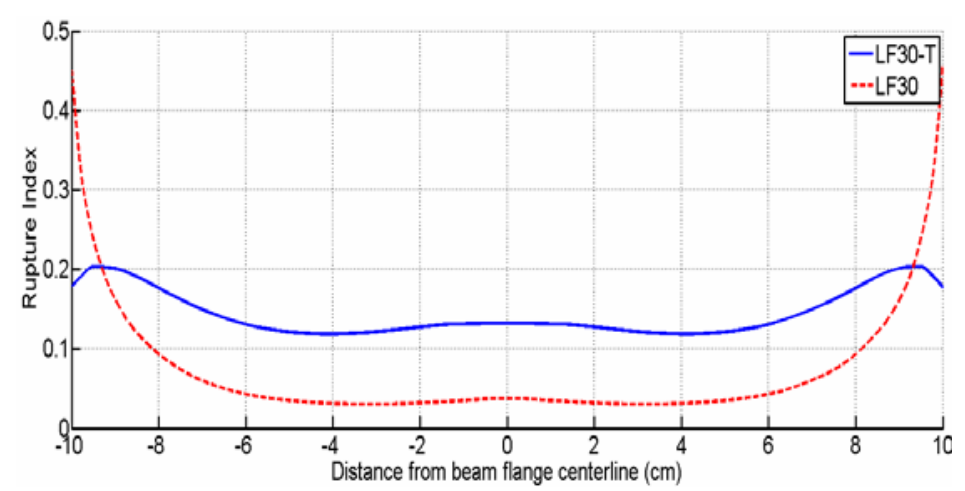

Figure 10. Distribution of Rupture Indices on Beam Flange at the Nose of Reinforcing Plate

- Length of the Flange Plate

The effect of flange plate length on the response of reinforced connections was investigated in this research. To assess the effect of flange plate length on the behavior of connections, the responses of two specimens LF30-T and LF50-T are compared below.

The distributions of the RI for LF30-T and LF50-T on the beam bottom flange at the nose of the reinforcing plate are shown in Figure 11. The maximum RI value of LF50-T is approximately $15 \%$ larger than that of LF30-T. This indicates that a longer flange plate increases values of RI at the nose of the reinforcing plate. There is a possible explanation for this phenomenon: 


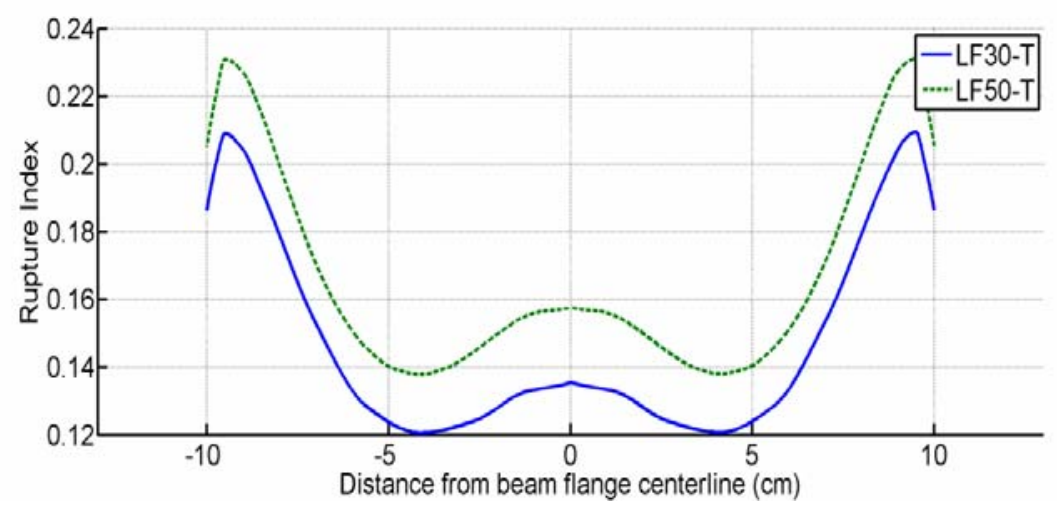

Figure 11. Distribution of Rupture Indices on Beam Flange at the Nose of Reinforcing Plate

A longer flange plate results in a higher plastic strain at the nose of reinforcing plate due to an increase in the beam plastic rotation. Eq. 1 shows that the higher plastic strain can results in higher RI value.

\subsubsection{Global Response of Flange Plate Connections}

In this section, the global behavior of models LF30 and LF30-T was evaluated before experimental studies. A displacement-control loading in the beam tip was induced in compliance with AISC seismic provisions loading history, which is shown in Figure 12. Equivalent plastic strain contours for models LF30 and LF30-T are presented in Figure 13. The key observations from Figure 13 are (1) the maximum plastic strain occurs at the end of the longitudinal fillet weld of model LF30 and (2) in models LF30 and LF30-T, plastic hinge forms away from the column flange into the beam beyond the nose of flange plates.

The moment at the column face versus story drift angle $(\theta)$ relationship for model LF30-T is shown in Figure 14. Story drift angle is computed by dividing the total beam tip displacement by the distance from the beam tip to the column centerline. The hysteretic curve for model LF30 was identical to model LF30-T.

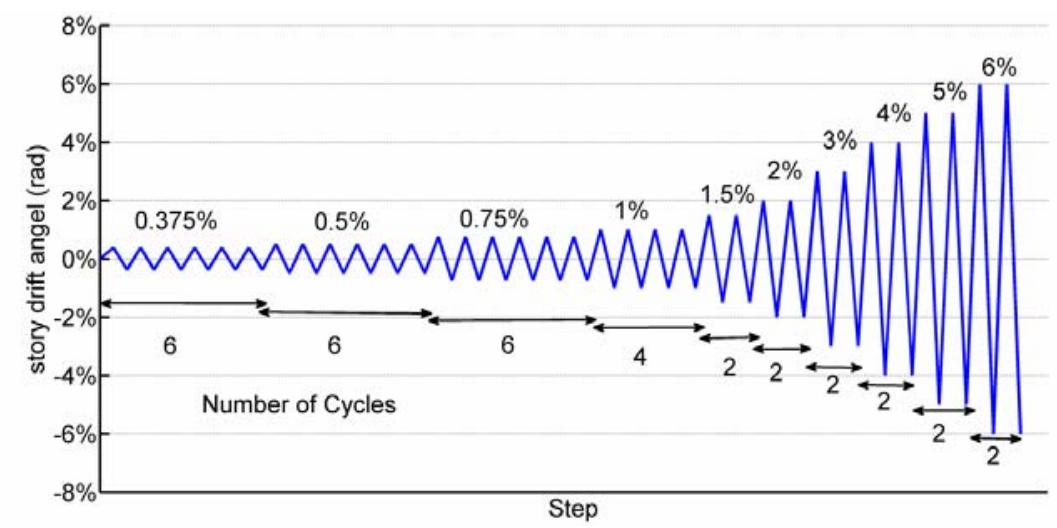

Figure 12. Cyclic Loading History 


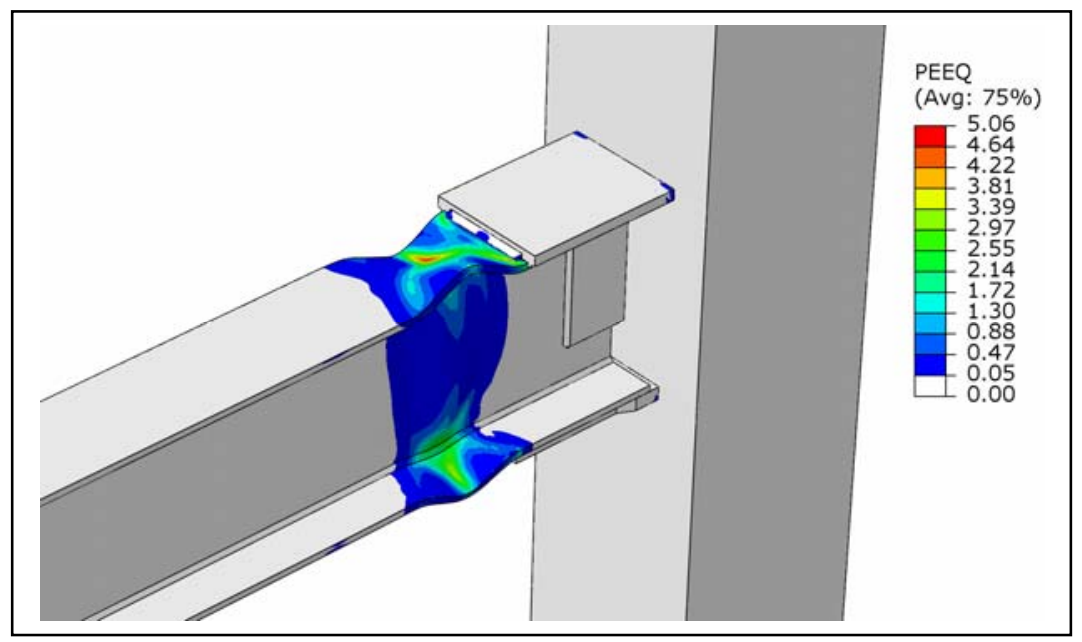

a)

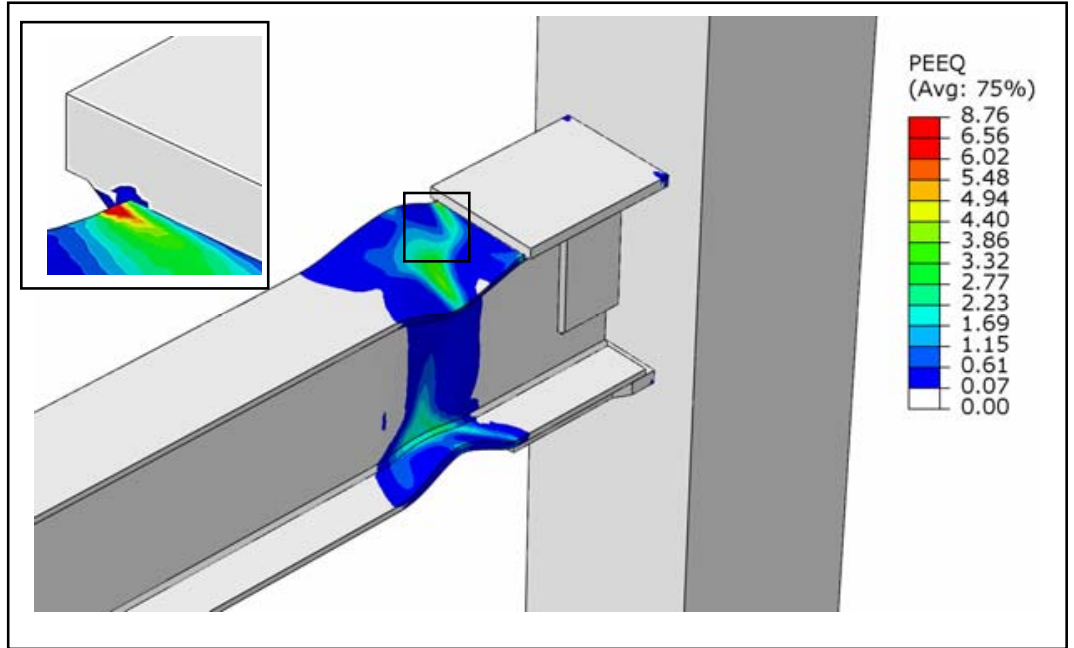

b)

Figure 13. Equivalent Plastic Strain Contours for Models a)LF30 and b)LF30-T

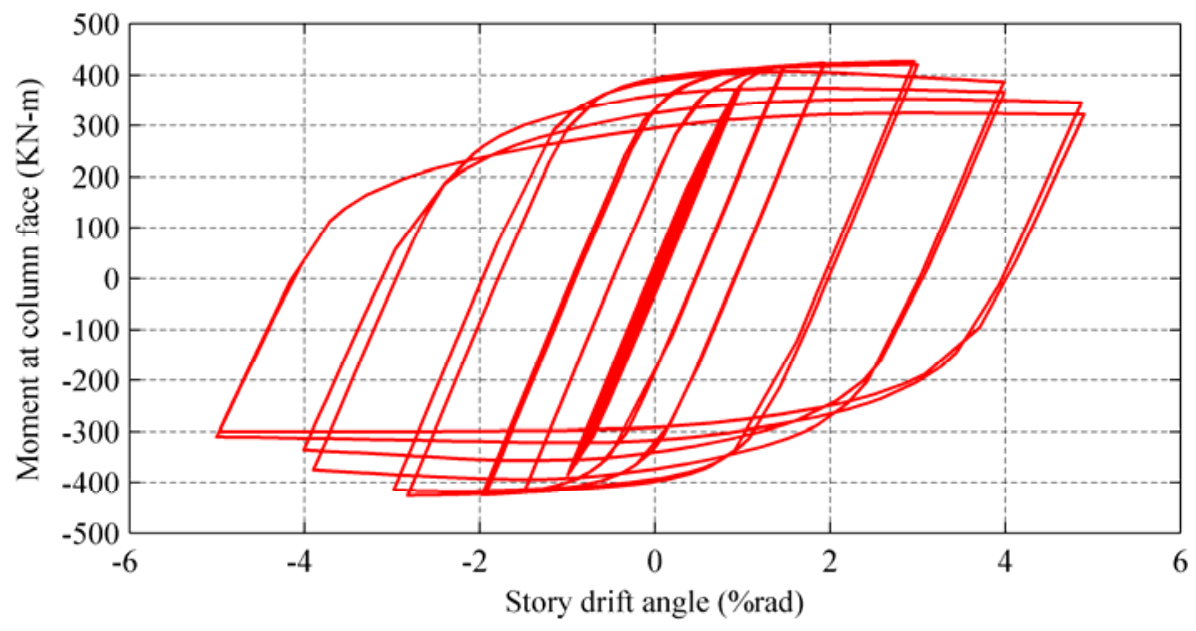

Figure 14. Cyclic Response of Model LF30-T 


\section{EXPERIMENTAL PROGRAM}

Two full scale test specimens with the same dimensions and connection details of models LF30-T and LF30 were fabricated and were subjected to cyclic loading. Figure 15 depicts the welding details for the test specimen LF30-T. The testing procedure and test results for global and local seismic behavior of the test specimens are discussed in the following sections.

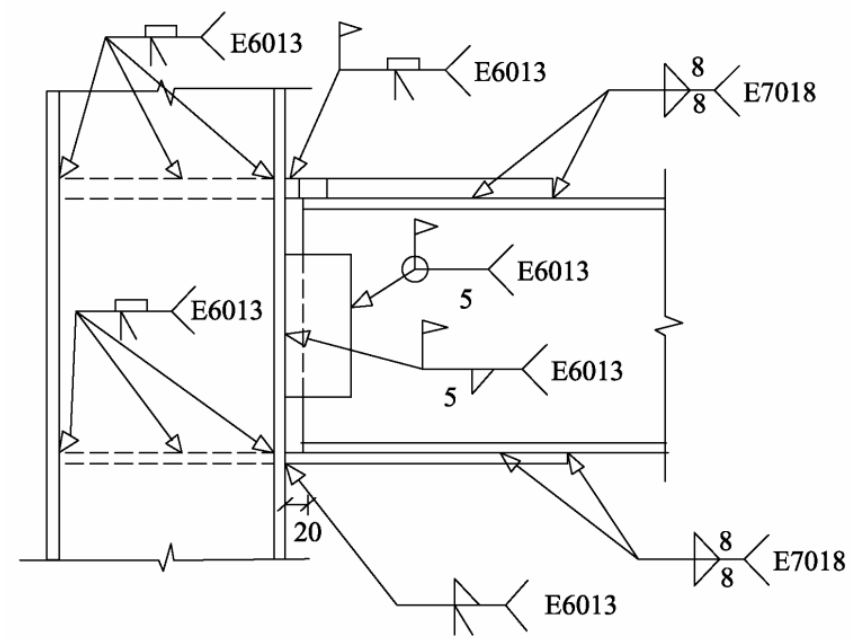

Figure 15. Welding Details for the Test Specimen LF30-T

\subsection{Test Setup and Instrumentation}

According to the shape of the specimen, a test setup was prepared to simulate the boundary conditions of the exterior joint subassembly in a laterally loaded moment frame. The column top and bottom was supported by real hinges. The beam was laterally braced in the vicinity of the plastic hinge and also near the beam end. The general configuration of the test setup and test specimen is shown in Figure 16.

The cyclic displacement was applied at the tip of the beam by a hydraulic actuator. The hydraulic loading system, mounted between the reaction frame and the beam tip, consisted of a $1000 \mathrm{KN}$ hydraulic actuator with $150 \mathrm{~mm}$ equal stroke for both forward and backward directions and also a load cell placed on the tip of a hydraulic actuator to record the applied loads. The actuator displacement is measured via both an internal displacement transducer of the actuator and an external LVDT. The specimen was cleaned and strain gauges were pasted at several locations. Whitewash was also painted on specimens in order to monitor the inelastic deformation during the test.

\subsection{Loading History}

The specimens were subjected to the loading sequence proposed by AISC seismic provisions for testing of beam-to-column moment connections [20]. Cyclic loading history is shown in Figure 12. The test was stopped at 5\% rad story drift to avoid damage to the hydraulic actuator. 


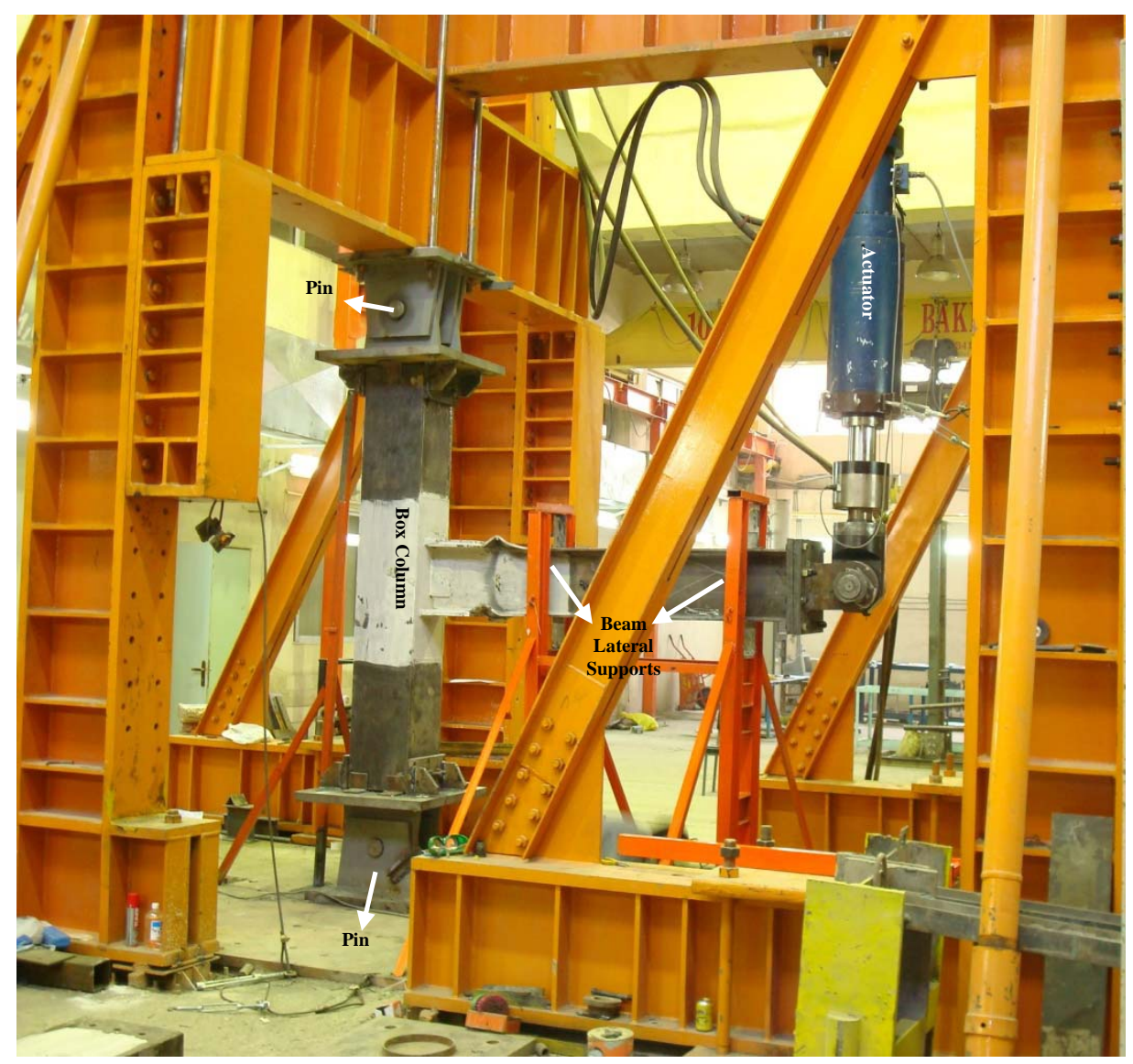

Figure 16. Test Setup Configuration

\subsection{General Test Observations}

\subsubsection{Specimen LF30-T}

The yielding of the specimen LF30-T was initiated in beam flanges during the first cycle of $1.5 \%$ story drift and during 3\% story drift, yielding extended into the beam web and spread about 300 $\mathrm{mm}$ along the beam flanges. Local buckling of the beam flanges was noticed in the cycles with $4 \%$ rad story drift angle. In the cycles of 5\% rad story drift angle, amplitude of beam local buckling was increased. At the end of the test, no signs of fracturing were observed except that minor cracking was noticed at the k-line of the beam bottom flange during the second cycle of $5 \% \mathrm{rad}$ story drift angle, as shown Figure 17. Figure 18 shows that the plastic hinge formed away from the face of the column in the beam beyond the nose of the reinforcing plate.

\subsubsection{Specimen LF30}

Just one difference between behavior of specimens LF30 and LF30-T was observed:

In the specimens LF30, the beam flange buckles penetrated beyond the nose of the flange plate toward the face of the column and tore the end of the longitudinal fillet weld. Figure 19 shows this tearing. But the transverse fillet welds joining the LF30-T flange plates to the beam flanges prevented the buckle penetration observed in LF30 and no tearing of the LF30-T fillet welds was observed. 


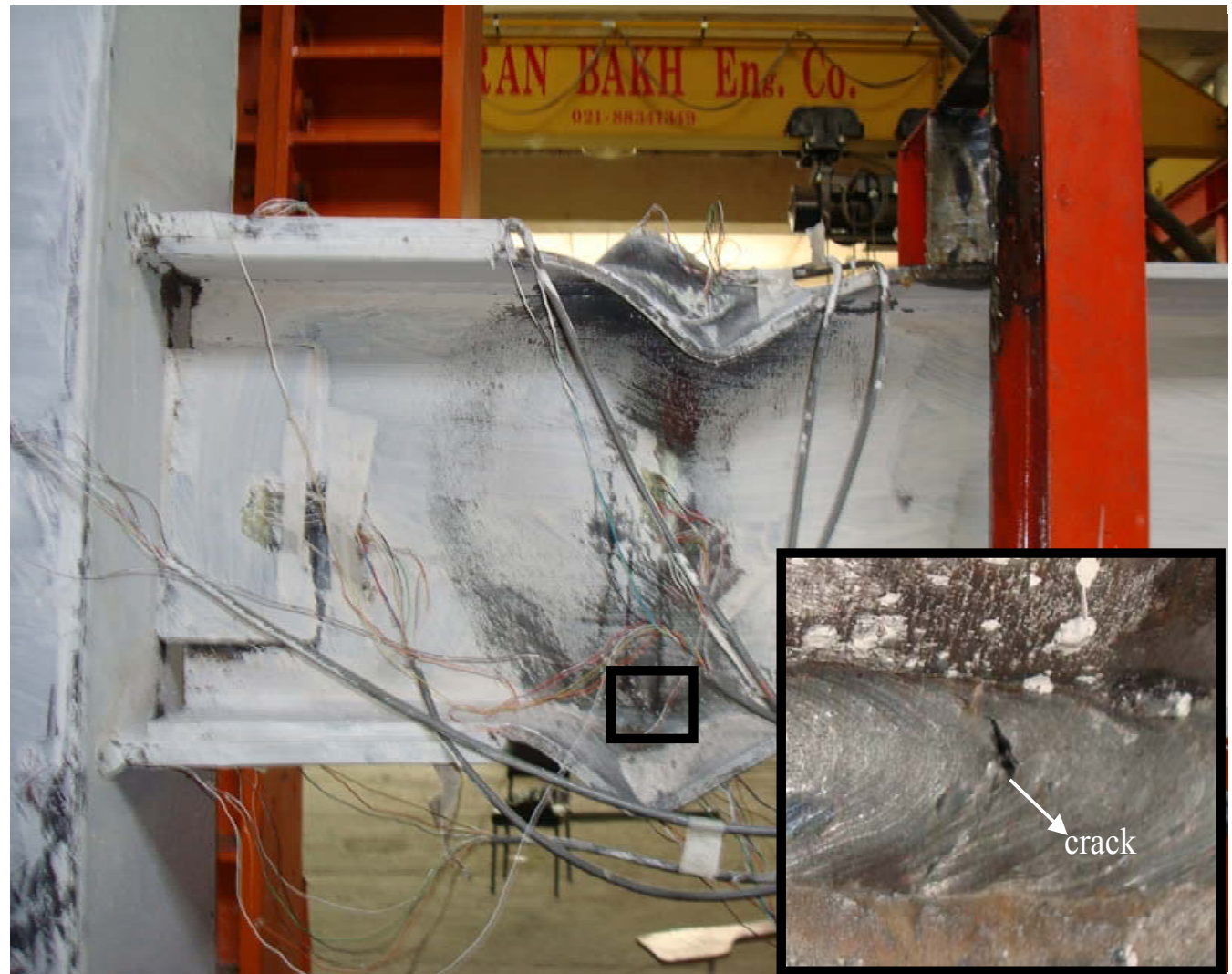

Figure 17. Minor Cracking at the k-line of the

Beam Bottom Flange at 5\% Rad in Specimen LF30-T

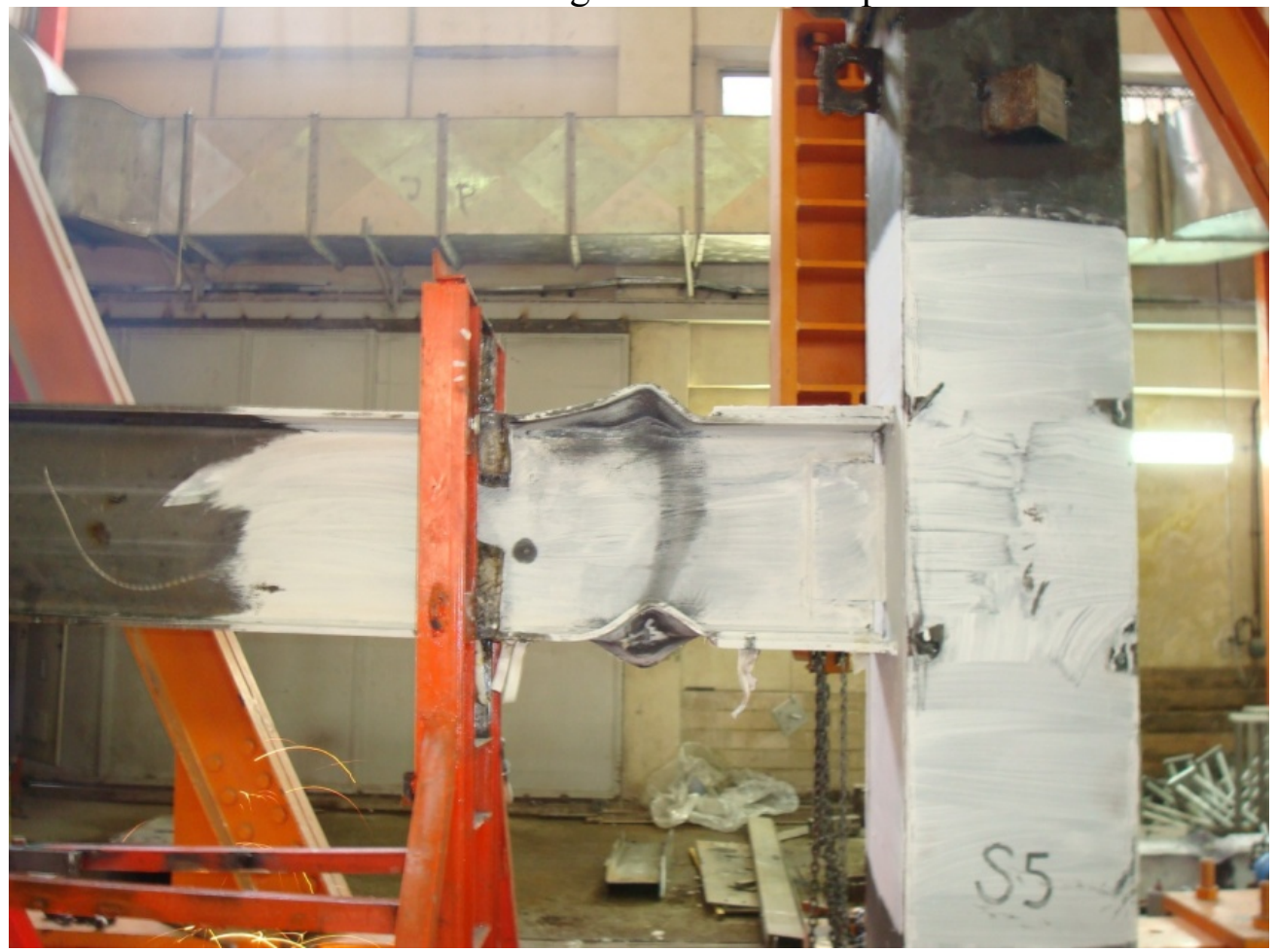

Figure 18. Specimen LF30-T at the End of the Test 


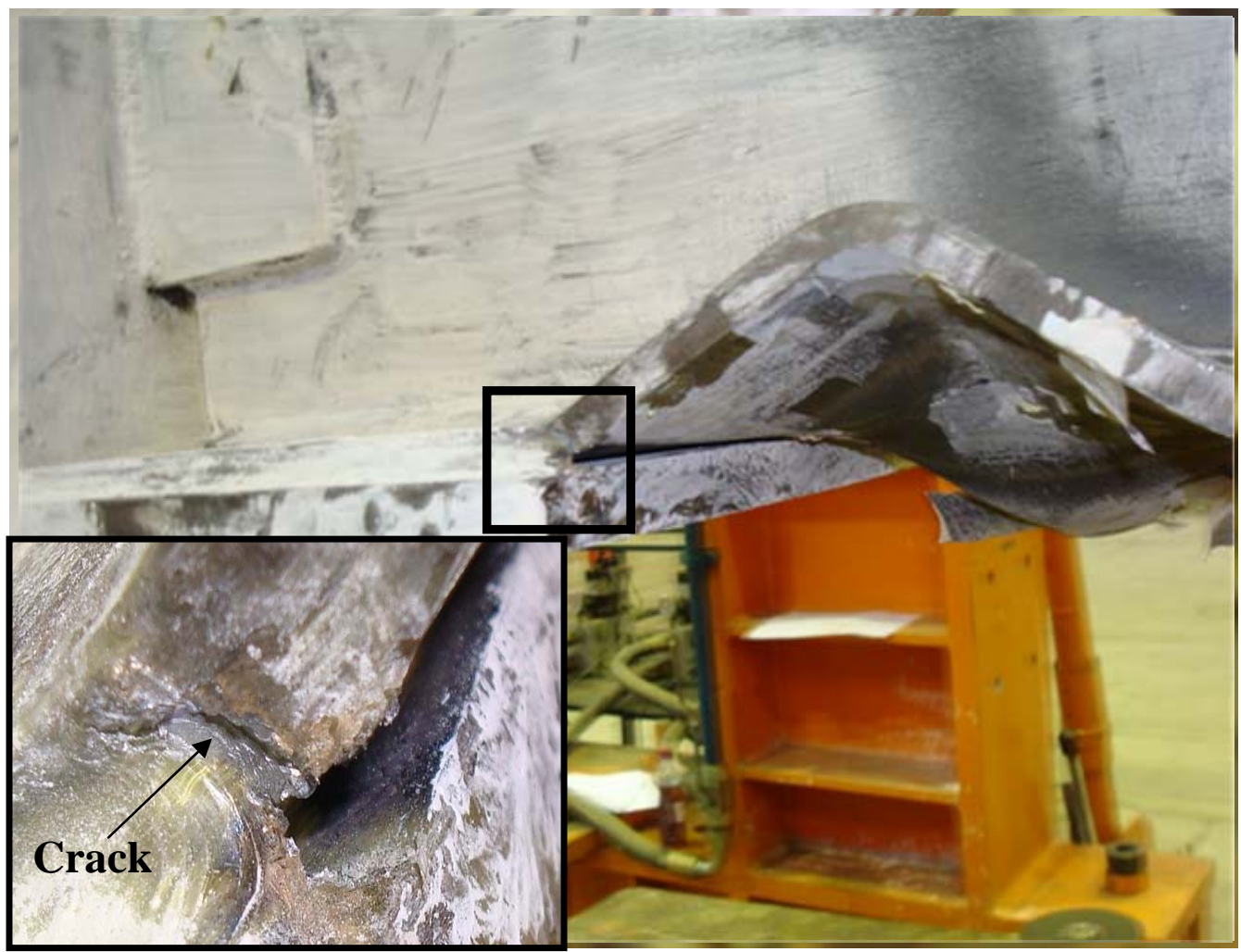

Figure 19. Crack in the Beam Flange at the End of the Longitudinal Fillet Weld of Specimen LF30

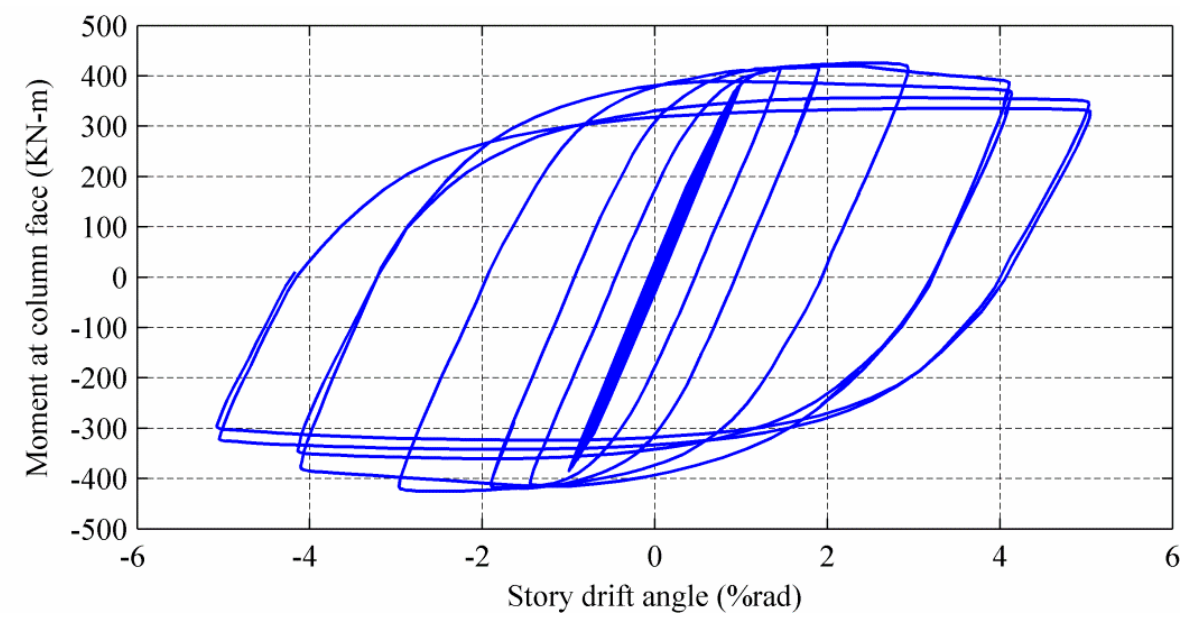

Figure 20. Moment at the Column Face Versus Story Drift Angel Relationship

\subsection{General Evaluation of the Connection Behavior}

The moment at the column face versus story drift angle $(\theta)$ relationship for the test specimen LF30-T is shown in Figure 20. The cyclic response of test specimen LF30 was identical to LF30-T. The results showed fair agreement between both experimental (Figure 20) and analytical (Figure 14) responses. In order to have a good comparison between analytical and experimental results a combined plot is illustrated in Figure 21. 
According to the AISC seismic provision [20] Beam-to-column connections used in special moment frames shall satisfy the following requirement:The measured flexural resistance of the connection, determined at the column face, shall equal at least $0.80 \mathrm{Mp}$ of the connected beam at an inter story drift angle of 0.04 radians. Figure 20 indicates that Moment resistances of test specimens were more than $80 \%$ plastic moment of beam at $4 \%$ total story drift. Therefore flange plate connections of test specimens achieved the AISC seismic provision requirements for special moment frames. It should be noted that the strength degradation of the specimens resulted from ductile local and global buckles during the cyclic loading and no significant fracture was occurred in the specimen.

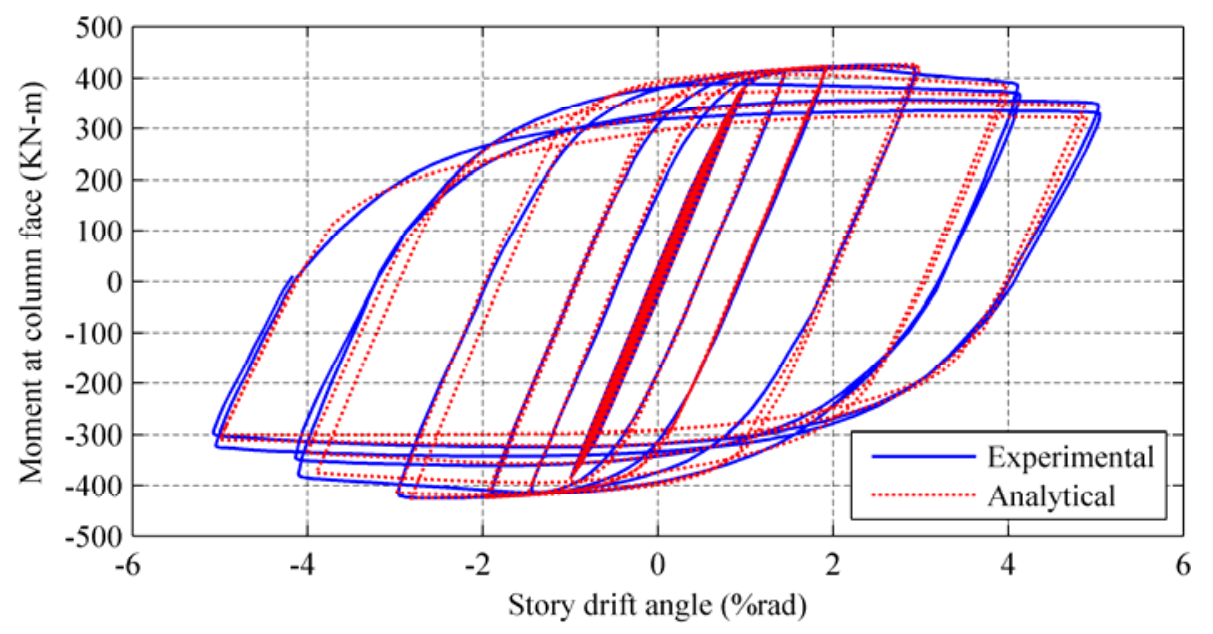

Figure 21. Comparison of the Experimental and Analytical Results

\subsection{Strains in Flange Plate and Beam Flange}

Figure 22 presents the relationship between axial strain and the story drift angle in the bottom flange plate and beam flange for specimen LF30. The maximum axial strain was recorded at the end of the longitudinal fillet weld joining the flange plate to the beam flange: the crack initiation site for specimen LF30. The maximum measured axial strain on the top surface of the flange plates in LF30, $50 \mathrm{~mm}$ from the column face, was approximately 5 times the yield strain. Such inelastic strains had no apparent deleterious effect on the response of either specimen. Beyond the $5 \%$ story drift, the strains in the flange e plates reduced slightly because of local buckling in the beam flange $\mathrm{s}$ and web and the consequent loss of strength in the beam. 

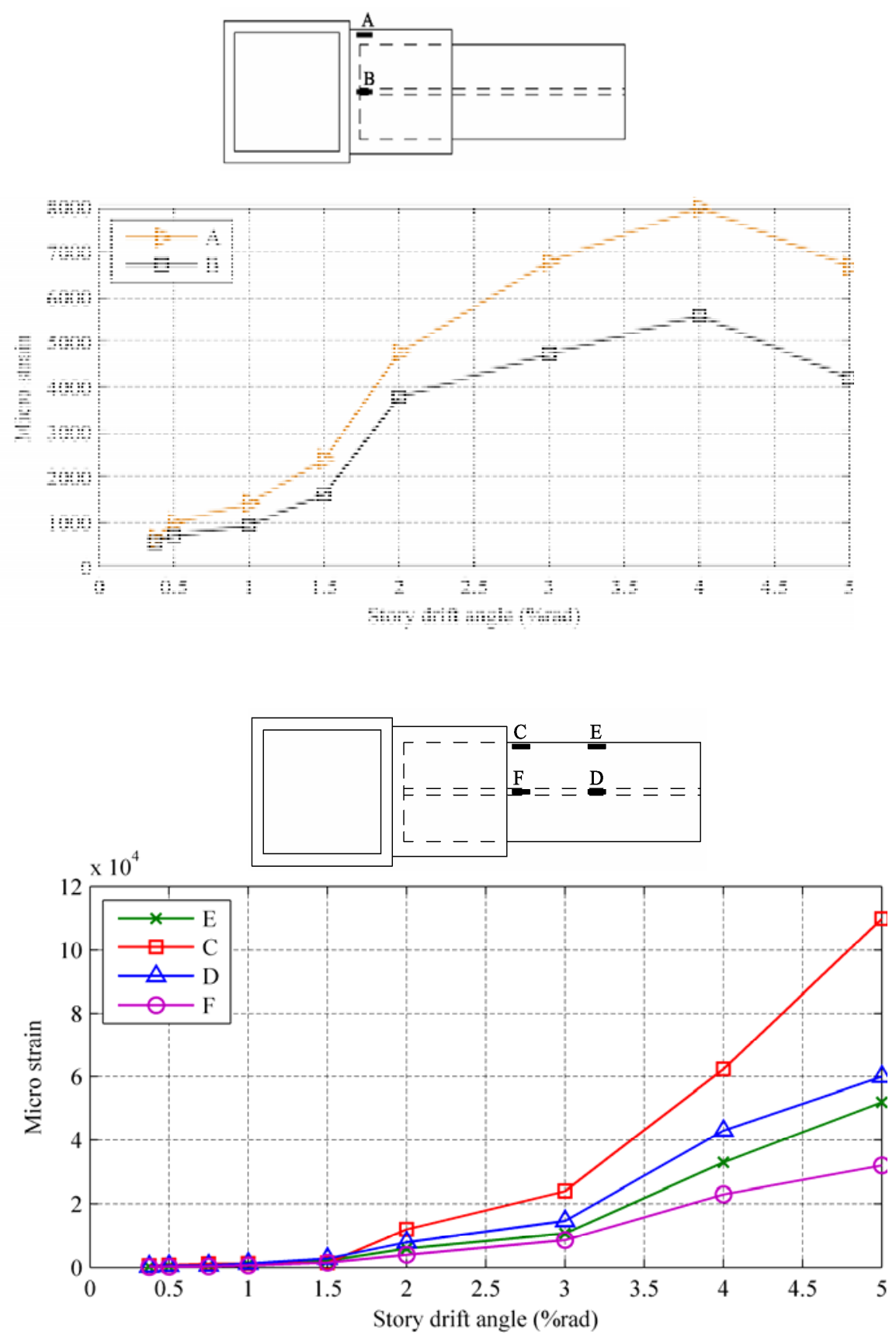

Figure 22.The relationship between axial strain and the story drift angle in the bottom flange plate and beam flange for specimen LF30

\section{CONCLUSIONS}

Two full-size specimens with flange plat connections were tested. Each specimen composed of a $\mathrm{H}$-shaped steel beam with the dimensions of $\mathrm{H}-380 \times 200 \times 8 \times 12(\mathrm{~mm})$ connected to a box column with the measurements of B-400 $\times 400 \times 20 \times 20(\mathrm{~mm})$. In the one of specimens, flange plates were joined to the beam flanges with longitudinal fillet welds only. The flange plates of other specimen were joined to the beam flanges with longitudinal and transverse fillet welds. Flange plate connections of test specimens achieved the AISC seismic provision requirements for special moment frames. 
The key conclusions drawn from the analytical studies and the associated experimental results are:

1. In the test specimens, no damage was observed at the groove welds joining flange plates to column flange. Because use of flange plate reduces potential for fracture at column face.

2. Analytical analysis indicated that use of transverse fillet weld at the nose of flange plate will reduce potential for fracture at the end of longitudinal fillet welds. This result was confirmed by the tests conducted for two full-scale specimens. .

3. It is better that the required flange plate length be limited to shortest possible length using weld of higher strength and increasing weld thickness to the maximum allowable limit.

\section{REFERENCES}

[1] Nakashima, M., Roeder, C.W. and Maruoka, Y., "Steel Moment Frames for Earthquakes in United States and Japan”, J. Struct. Eng., ASCE 2000, Vol. 126, No. 8, pp. 861-8.

[2] Del Savio, A.A, Nethercot, D.A., Vellasco, P.C., de Lima L.R.O., Andrade, S.A.L. and Martha, L.F., " An Assessment of Beam-to-Column Endplate and Baseplate Joints Including the Axial-Moment Interaction", Advanced Steel Construction, 2010, Vol. 6, No. 1, pp. 548-566.

[3] Arul Jayachandran, S., Marimuthu, V., Prabha, P., Seetharaman, S. and Pandian, N., "Investigations on the Behaviour of Semi-Rigid Endplate Connections", Advanced Steel Construction, 2009, Vol. 5, No. 4, pp. 432-451.

[4] Tabar, A.M. and Deylami, A., "Instability of Beams with Reduced Beam Section Moment Connections Emphasizing the Effect of Column Panel Zone Ductility”, Journal of Constructional Steel Research, 2005, Vol. 61, No. 11, pp. 1475-1491.

[5] Tabar, A.M. and Deylami, A., "Investigation of Major Parameters Affecting Instability of Steel Beams with RBS Moment Connections", Steel and Composite Structures, Vol. 6, No. 3, pp. 1475-1491.

[6] Shiravand, M.R. and Deylami, A., "Application of Full Depth Side Plate to Moment Connection of I-Beam to Double-I Column", Advances in Structural Engineering, 2010, Vol. 13, No. 6, pp. 1047-1062.

[7] Adeli, M., Banazadeh, M. and Deylami, A., "Bayesian Approach for Determination of Drift Hazard Curves for Generic Steel Moment-resisting Frames in Territory of Tehran", International Journal of Civil Engineering, 2011, Vol. 9, No. 3, pp. 145-154.

[8] Chen, C.C., Lin, C.C. and Tsai, C.L.," Evaluation of Reinforced Connections between Steel Beams and Box Columns", Engineering Structures, 2004; Vol. 13, pp.1089-1092.

[9] Kim, T., Stojadinovic, B. and Whittaker, A.S., "Seismic Performance of US Steel Box Column Connections", Proceedings, 13th World Conference on Earthquake Engineering, Canada, 2004, Paper No. 981.

[10] Kim, T., "Experimental and Analytical Performance Evaluation of Welded Steel Moment Connections to Box or Deep W-shape Columns", PhD Dissertation, University of California, Berkeley, CA, 2003.

[11] FEMA. Recommended Seismic Design Criteria for New Steel Moment Frame Buildings, Report No. FEMA-350, Federal Emergency Management Agency, 2000.

[12] Kim, T., Whittaker, A.S., Gilani, A.S.J., Bertero, V.V. and Takhirov, S.M., "Experimental Evaluation of Plate-reinforced Steel Moment-resisting Connections", Journal of Structural Engineering, ASCE 2002, Vol. 128, No. 4, pp. 483-491. 
[13] Kim, T., Whittaker, A.S., Gilani, A.S.J., Bertero, V.V. and Takhirov, S.M.," Cover-plate and Fange-plate Steel Moment-resisting Connections", Journal of Structural Engineering, ASCE 2002;128(4):474-482.

[14] Kaufmann, E.J., "Dynamic Tension Tests of Simulated Moment Resisting Frame Weld Joints", Chicago", Steel Tips, Structural Steel Education Council, American Institute of Steel Construction, 1997.

[15] Mao, C., Ricles, J.M., Lu, L.W., Fisher, J.W., "Effect of Local Details on Ductility of Welded Moment Connections", Journal of Structural Engineering, ASCE, 2001, Vol. 127, No. 9, pp. 1036-1044.

[16] Ricles, J.M., Fisher, J.W., Lu, L.W. and Kaufmann, E.J.," Development of Improved Welded Moment Connections for Earthquake-resistant Design", Journal of Constructional Steel Research 2002, Vol. 58, pp. 565-604.

[17] Ricles, J.M., Mao, C., Lu, L.W. and Fisher, J.W.," Ductile Details for Welded Unreinforced Moment Connections Subject to Iinelastic Cyclic Loading”, Engineering Structures 2003, Vol. 25, pp. 667-680.

[18] El-Tawil, S., Mikesell, T., Vidarsson, E. and Kunnath, S.," Strength and Ductility of FR Welded-bolted Connections", Report No. SAC/BD-98/01, SAC Joint Venture, Sacramento, CA, 1998.

[19] Hancock, J.W. and Mackenzie, A.C.," On the Mechanisms of Ductile Failure in High Strength Steels Subjected to Multi-axial Stress States", Journal of the Mechanics and Physics of Solids, 1976, Vol. 24, pp. 147-169.

[20] AISC, Seismic Provisions for Structural Steel Buildings, Chicago (IL) American Institute of Steel Construction; 2002. 